POWERS OF THE SECULAR MODERN 



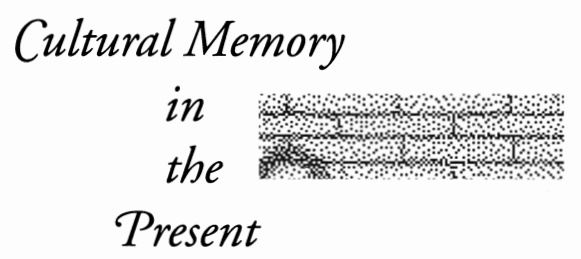

Mieke Bal and Hent de Vries, Editors 



\section{POWERS OF THE SECULAR MODERN}

Talal Asad and His Interlocutors

Edited by David Scott and Charles Hirschkind

STANFORD UNIVERSITY PRESS

STANFORD, CALIFORNIA

2006 
Stanford University Press

Stanford, California

(C) 2006 by the Board of Trustees of the

Leland Stanford Junior University.

All rights reserved.

No part of this book may be reproduced or transmitted in any form or by any means, electronic or mechanical, including photocopying and recording, or in any information storage or retrieval system without the prior written permission of Stanford University Press.

\section{Library of Congress Cataloging-in-Publication Data}

Powers of the secular modern : Talal Asad and his interlocutors / edited by David Scott and Charles Hirschkind.

p. cm. - (Cultural memory in the present)

Includes bibliographical references and index.

ISBN 0-8047-5265-6 (cloth : alk. paper)

ISBN 0-8047-5266-4 (pbk. : alk. paper)

I. Ethnology-Philosophy. 2. Ethnology-Eastern Hemisphere-

Philosophy. 3. Postcolonialism-Eastern Hemisphere. 4. SecularizationEastern Hemisphere. 5. Asad, Talal-Criticism and interpretation.

I. Scott, David, 1958- II. Hirschkind, Charles. III. Series.

GN345.P66 2006

306. . I- $-\mathrm{dc} 22$

2005013565

Original Printing 2006

Last figure below indicates year of this printing:

$\begin{array}{llllllllll}\text { I5 } & \text { I4 } & \text { I3 } & \text { I2 } & \text { II } & \text { IO } & 09 & 08 & 07 & 06\end{array}$ 
For Tanya 
